\title{
El-Fayah
}

JURNAL BIOLOGI

Journal Homepage: http://ejournal.uin-malang.ac.id/index.php/bio/index

e-ISSN: 2460-7207, p-ISSN: 2086-0064

Original research article

\section{Analysis Macrozoobenthos Diversity in Way Kalam Waterfall Tourism Lampung Selatan Regency}

\author{
Fatika Septiarila \\ Biology Education Study Program, FTK Raden Intan State Islamic University Lampung \\ *Corresponding author \\ Email: fatika.septi@gmail.com \\ DOI: $10.18860 /$ elha.v8i3.13528
}

\begin{tabular}{l} 
A r t i c l e I n f o \\
\hline Article history: \\
Received 24 May 2021 \\
Received in revised form \\
24 May 2021 \\
Accepted 03 July 2021 \\
\hline Key Word: \\
Diversity Index \\
Macrozoobenthos \\
Way Kalam Waterfall
\end{tabular}

\section{INTRODUCTION}

The body of water on the earth's surface both fresh and brackish which leads from the lowest tidal line towards the land is called fresh water [1]. The river is included in one type of fresh water which starts from the upstream and ends at the downstream, has an elongated shape on the earth's surface [2]. The elongated river flow sometimes falls from the cliff on the river bank to form a waterfall,

\begin{abstract}
This study aims to determine the diversity index of macrozoobenthos and determine the physico-chemical parameters that exist in Way Kalam Waterfall Tourism, South Lampung. This type of research is descriptive quantitative, sampling was carried out at three research stations including macrozoobenthos samples and measurements of physical and chemical parameters of the waters (temperature, brightness, $\mathrm{pH}, \mathrm{DO}$, COD, and BOD) using purposive random sampling technique. Sampling macrozoobenthos on the bottom of the water using a shovel. The results showed that the obtained macrozoobenthos consisted of 3 phyla, 4 classes, 6 orders, 9 families, and 63 individuals. The macrozoobenthos diversity index value obtained was in the moderate category. The diversity index value is in the stable community category, and the dominance index is in the low category. The results of the measurement of physical parameters and chemical parameters showed that the waters of the Way Kalam Waterfall tour were not polluted.
\end{abstract}

falling water from the top of the cliff hits the base to form a waterfall pool [3].

Industrial activities and household activities make fresh water the main source of necessities in life [4]. The river is one type of freshwater body that supports human activities, as a supporter in the activities of human life that are not environmentally friendly causing the river to be burdened due to decreased carrying capacity [5]. 
Changes in the ecological balance due to the influence of waste can be seen through biological indicator organisms, environmental quality parameters can be measured through the presence of organisms in it [6]. Aquatic organisms that can be used as biological indicators of the aquatic environment are macrozoobenthos. Macrozoobenthos are animals that inhabit the bottom of the waters attached, crawl or dig holes so that most or all of their life cycle is on the bottom of the waters [7].

Macrozoobenthos is very sensitive to changes in aquatic environmental conditions, so that the abundance and diversity of macrozoobenthos is influenced by the physical and chemical properties of a waters. Physical and chemical properties of waters in the form of depth, current speed, color, turbidity, brightness, water temperature, $\mathrm{pH}, \mathrm{DO}, \mathrm{COD}$, and BOD [8]. So to find out whether there has been pollution or not, it can be seen through physical and chemical indicators, a water is said to be good if the organisms in it can grow well [9]. Macrozoobenthos organisms can be quantified by determining the number of species, abundance, average, and species diversity, this is what makes macrozoobenthos can be used as an ecological indicator of an aquatic environment. The easy quantification of the macrozoobenthos indicates that the macrozoobenthos qualifies as a bioindicator [6].

The river flow in the Way Kalam Waterfall area is one of the habitats of macrozoobenthos, the Way Kalam Waterfall area is a tourist attraction located in Way Kalam Village, South Lampung Regency. The problem that arises in this study is that there is no data regarding the diversity of macrozoobenthos in the area, while the flow of the Way Kalam Waterfall is very important as a habitat for macrozoobenthos. The activities of visitors who travel to Way Kalam Waterfall will affect the environmental conditions of the river waters which have an impact on the diversity of macrozoobenthos contained in it.

\section{MATERIALS AND METHODS}

The study was carried out in February 2021. Research location located in Way Kalam Waterfall Tourism, Penengahan District, South Lampung Regency, Lampung Province. The tools and materials used in this study include a $\mathrm{pH}$ meter, a filter with a $1 \mathrm{~mm}$ filter eye, a paralon, a shovel, a thermometer with a 0-100 ${ }^{\circ} \mathrm{C}$ scale, a sechi disk, a wooden stick, a ruler, a microscope, label paper, raffia string, tweezers, tools writing, camera, formalin $4 \%$, alcohol $70 \%$, and aquades.

This type of research is descriptive quantitative, namely the type of research that describes phenomena in a systematic, factual, and accurate manner regarding the facts and characteristics of a particular population. Therefore, quantitative descriptive research is a systematic effort in answering a problem and obtaining in-depth information from a phenomenon by using the stages of quantitative research [10]. The population in this study were macrozoobenthos organisms in the Way Kalam Waterfall river, and the samples taken were a group of macrozoobenthos organisms that had the number and characteristics of the macrozoobenthos population. The sampling technique was purposive random sampling, namely taking samples based on predetermined objectives. The observed samples consisted of three parameters, namely biology, physics, and chemistry.

Macrozoobenthos sampling carried out at 3 stations with 2 repetitions in each station, sampling using a shovel by dredging the bottom of the water, the dredging results are then separated from the substrate by filtering with water. The sample was then put into a glass bottle and fixed with $4 \%$ formalin at the study site. Observation of macrozoobenthos samples was carried out in the Biology laboratory of UIN Raden Intan Lampung. The samples that had been observed under a microscope with a magnification of 40-1000 times were then identified using the Invertebrate Identification Guide, Research 
and Cumulative Watershed Effects, and Invertebrate Zoology books.

Analysis of macrozoobenthos data was calculated using the Shanon-Wienner diversity index, Evennes uniformity index, and Simpson dominance index.

\section{a) Diversity index}

The calculation of the diversity index using the Shanon-Wienner equation:

$$
H^{\prime}=-\sum_{i=1}^{s} P i \ln P i
$$

Information:

$\mathrm{H}^{\prime} \quad$ = Shanon-Wienner Diversity Index

$\mathrm{s}=$ Number of individuals/species in the community

$\mathrm{Pi}=$ Proportion of the ith species to the total number or total number [11]

The criteria for the Shanon-Wienner diversity index [12]:

- $H^{\prime} \leq 1$ : low diversity

- $1 \leq \mathrm{H}^{\prime} \leq 3$ : moderate diversity

- $\mathrm{H}^{\prime} \geq 3$ : high diversity

b) Uniformity Index

The uniformity index calculation uses the Evennes uniformity index equation:

$$
E=\frac{H^{\prime}}{H^{\prime} \operatorname{Max}} \text { atau } \frac{H^{\prime}}{\ln (S)}
$$

Information:

$\mathrm{E}=$ Evennes uniformity index

$H^{\prime}$ Max = Shanon-Wienner Diversity Index

$\mathrm{S}=$ Total number of species

With a range of uniformity index values [12]:

- $0,0<E<0,5: \quad$ Uniformity depressed/low type

- $0,5<E<0,75:$ Medium type uniformity/unstable

- $0,75<\mathrm{E}<1$ : High/stable type uniformity c) Dominance Index

The calculation of the dominance index uses the Simpson's dominance index formula:

$$
\begin{aligned}
D & =\sum(\mathrm{ni} / \mathrm{N})^{2} \\
\text { Information: } & \\
\mathrm{D} & =\text { Simpson dominance index } \\
\mathrm{ni} & =\text { Number of individuals per species } \\
\mathrm{N} & =\text { Number of individuals of all species }
\end{aligned}
$$

The dominance index value is said to be high if the total abundance is strongly dominated by a species, which is between $0-1$, on the other hand, the dominance index value is said to be low (close to 0 ) if between species have relatively the same abundance [13]

\section{RESULTS and DISCUSSION}

The results of observations of macrozoobenthos found in the Way Kalam Waterfall stream from 3 observation stations came from the Gastropod class consisting of the Pleurocerida, Thiaride, and Pachychilidae families, the Crustacea class consisting of the Palaemonidae and Penaeidae families, the Oligochaeta class consisting of the Lumbricidae and Tubificidae families, and the class Insecta which consists of the families Chironomidae and Heptageniidae. The macrozoobenthos organisms were spread over the three research stations, at station I there was 1 animal from the family Tubificidae, 1 animal from the family Thiaridae, 1 animal from the family Pleuroceridae, 9 animals from the family Pachychilidae, 1 animal from the family Chironomidae, 1 animal from the family Palaemonidae, and 4 animals from the family Panaeidae. At station II obtained 3 animals from the family Tubificidae, 2 animals from the family Lumbricidae, 3 animals from the Thiaridae family, 2 animals from the Pleuroceridae family, 8 animals from the Pachychilidae family, 1 animal from the Heptageniidae family, and 6 animals from the Penaeidae family. At station III obtained 2 
animals from the family Tubificidae, 1 animal from the family Lumbricidae, 1 animal from the family Thiaridae, 2 animals from the family Pleuceridae, 8 animals from the family Pachychilidae, and 5 animals from the family Penaeidae. The total macrozoobenthos obtained consisted of 3 phyla, 4 classes, 6 orders, 9 families, and 63 individuals. Data on the number of identified macrozoobenthos can be seen in Table 1 below.

Table 1. Data on the number of identified macrozoobenthos

\begin{tabular}{|c|c|c|c|c|c|}
\hline \multirow{2}{*}{ No } & \multirow{2}{*}{ Family } & \multicolumn{3}{|c|}{ Number of Individual } & \multirow{2}{*}{ Number of Individual } \\
\hline & & Station I & Station II & Station III & \\
\hline 1 & Tubificidae & 1 & 3 & 2 & 6 \\
\hline 2 & Lumbricidae & 0 & 2 & 1 & 3 \\
\hline 3 & Thiaridae & 1 & 3 & 1 & 5 \\
\hline 4 & Pleuroceridae & 1 & 2 & 2 & 5 \\
\hline 5 & Pachychilidae & 9 & 8 & 8 & 25 \\
\hline 6 & Chironomidae & 1 & 0 & 0 & 1 \\
\hline 7 & Heptageniidae & 0 & 1 & 1 & 2 \\
\hline 8 & Palaemonidae & 1 & 0 & 0 & 1 \\
\hline 9 & Penaeidae & 4 & 6 & 5 & 15 \\
\hline \multicolumn{2}{|c|}{ Number of individual } & 18 & 25 & 20 & 63 \\
\hline
\end{tabular}
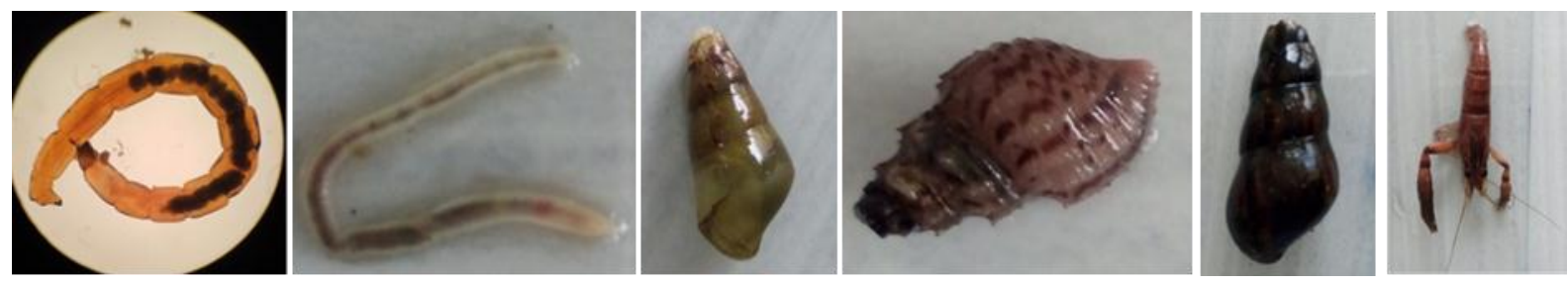

\begin{tabular}{|l|l|l|l|l|l|}
\hline A & B & C & D & E & F \\
\hline
\end{tabular}
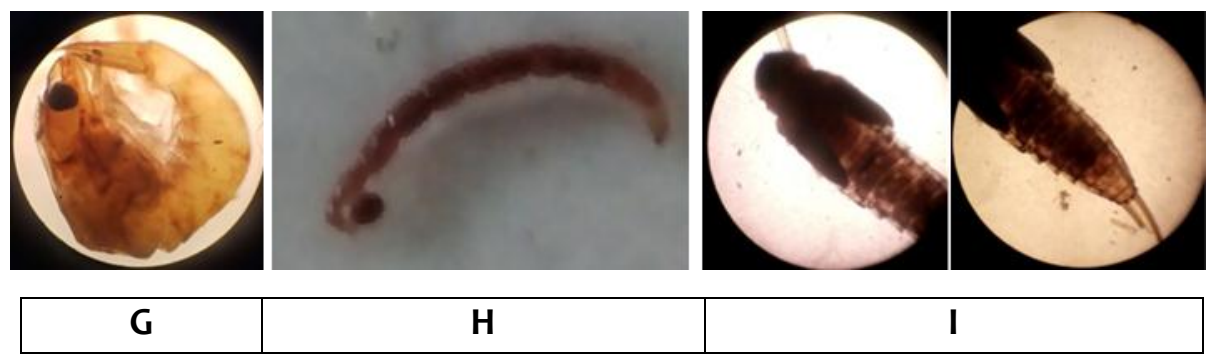

Figure 1. A. Tubificidae; B. Lumbricidae; C. Pleurocidae; D. Thiaridae; E. Pachychilidae; F. Palamonidae; G. Penaeinidae; H. Chiromonidae; I. Heptageniidae

The observed data that have been identified were then analyzed using the Shannon-Wienner diversity index $\left(H^{\prime}\right)$, the Evennes uniformity index and the Simpson dominance index (D). The results of the analysis can be seen in Table 2 below. 
Table 2. Diversity index, uniformity index, and dominance index

\begin{tabular}{|c|c|c|c|c|c|}
\hline \multirow{2}{*}{$\begin{array}{l}\mathrm{N} \\
\mathrm{O}\end{array}$} & \multirow{2}{*}{ Index } & \multicolumn{3}{|c|}{ Station } & \multirow{2}{*}{ Level } \\
\hline & & 1 & II & III & \\
\hline 1 & $\begin{array}{l}\text { Shannon- } \\
\text { Wiener } \\
\text { Diversity } \\
\left(\mathrm{H}^{\prime}\right)\end{array}$ & 1,124 & 1,335 & 1,205 & $\begin{array}{l}\text { Moderate } \\
\text { diversity }\end{array}$ \\
\hline 2 & $\begin{array}{l}\text { Evennes } \\
\text { Uniformity }\end{array}$ & 0,817 & 0,882 & 0,875 & $\begin{array}{l}\text { Specific } \\
\text { uniformity is } \\
\text { high/stable }\end{array}$ \\
\hline 3 & $\begin{array}{l}\text { Simpson's } \\
\text { Dominanc } \\
\text { e Index } \\
\text { (D) }\end{array}$ & 0,336 & 0,260 & 0,327 & $\begin{array}{l}\text { Low } \\
\text { dominance }\end{array}$ \\
\hline
\end{tabular}

Based on Table 2 above, it shows that the results of the analysis of the highest diversity index value are at station II at 1.335 and the lowest diversity index is at station I with a value of 1.124. The high diversity index at station II was due to the fact that at station II found families with more individuals than at other stations. This shows that from the three observation stations the diversity is in the moderate category. This is in accordance with what is described in the research results of the journal Marine and Aquatic Science that if the low diversity index value is included in the low category, it indicates that the waters are polluted, while the results of this study obtained the lowest diversity index value from 4 stations is $H^{\prime}=1,57$ where this value indicates that the condition of the community in these waters is stable, supported by the results of the diversity index at the other 3 stations which reached the number $H^{\prime}=2$. So that the overall condition of community diversity in these waters is stable and quite good [14].

Evennes uniformity index value at station I obtained a value of 0.817 , station II of 0.882 and station III of 0.875 . So that the highest uniformity index value is found at station II with a value of 0.882 and the lowest uniformity index is at station I of 0.817 . The uniformity index value is included in the category of stable community. In accordance with the results of research in the journal Sustainable
Environmental Management, the high uniformity index which is close to the maximum value (1.00) illustrates the distribution of the macrozoobenthos population is quite good, where at station IV and station $\mathrm{V}$ the dominance index values reach 0.83 and 0.89 , which means uniformity at both stations are quite good [15].

Furthermore, the highest Simpson dominance index value is found at station I with a value of 0.336 and the lowest dominance index value is found at station II with a value of 0.260 while the dominance index value of station III is 0.322 . This shows that there is no dominance in the flow of the Way Kalam Waterfall. The results of research in the journal Environmental Management suggest that the dominance index value is inversely proportional to the diversity index value and the uniformity index value, where the higher the diversity index value and the uniformity index value, the lower the dominance index value [15].

Measurement of physical parameters and chemical parameters from the three stations included temperature, brightness, $\mathrm{pH}, \mathrm{DO}$, COD, and BOD. The results of the measurement of physical parameters are presented in Table zand Table 4 below..

Table 3 Physical parameter data in the flow of Way Kalam Waterfall

\begin{tabular}{|c|c|c|c|c|c|}
\hline \multirow{2}{*}{$\begin{array}{l}\mathrm{N} \\
\mathrm{O}\end{array}$} & \multirow{2}{*}{ Parameter } & \multicolumn{3}{|c|}{ Station } & \multirow{2}{*}{$\begin{array}{l}\text { Quality } \\
\text { Standar } \\
\text { ds }\end{array}$} \\
\hline & & I & II & III & \\
\hline 1 & $\begin{array}{l}\text { Water } \\
\text { Temperat } \\
\text { ure }\left({ }^{\circ} \mathrm{C}\right)\end{array}$ & $21^{\circ} \mathrm{C}$ & $21{ }^{\circ} \mathrm{C}$ & $21{ }^{\circ} \mathrm{C}$ & $38^{\circ} \mathrm{C}$ \\
\hline 2 & Brightness & $20 \mathrm{~cm}$ & $20 \mathrm{~cm}$ & $17,5 \mathrm{~cm}$ & $<6 \mathrm{~m}$ \\
\hline
\end{tabular}

Measurement of temperature on physical parameters using a thermometer carried out at station I, station II, and station III showed the same results, namely $21{ }^{\circ} \mathrm{C}$, the same temperature value was obtained because the environment around the waterfall is a forest 
with a lot of vegetation so that it covers the direction of light entering. Sun. Based on the data obtained, the temperature value is still below the value of the quality standard based on PP no. 82 of 2001. In the regulation, the maximum water temperature is $38{ }^{\circ} \mathrm{C}$ so that the temperature at the three research stations is still in accordance with the criteria that have been set. So that the temperature range in the river flow is still good for the growth of macrozoobenthos. In accordance with previous research conducted by Emmanuel Manangkalangi regarding "Macro avertebrata benthos as Bioindicators of Water Quality in the Nimbai Manokwari River, West Papua" where the results of the study stated that the water temperature between research stations varied greatly depending on the measurement time, ranging from $24-32{ }^{\circ} \mathrm{C}$. In this study, it can be seen that lower water temperatures have higher macroinvertebrate diversity than other observation stations [16].

The results of the brightness measurement ranged from $17.5 \mathrm{~cm}-20 \mathrm{~cm}$. Based on the measurement results in the table above, the highest brightness is at stations I and II of 20 $\mathrm{cm}$, the lowest brightness level is at station III of $17.5 \mathrm{~cm}$. The brightness measurement has reached its maximum at the riverbed, due to the shallow condition of the river. Based on the determination of the quality standard (PP no. 82 of 2001) for water brightness $<6 \mathrm{~m}$, the brightness at the three research stations still meets the criteria. The brightness of the waters is a condition of the ability of sunlight to penetrate the water layer at a certain depth, the brightness of the waters is very important for aquatic biota especially in terms of photosynthesis and survival. The brightness of the waters is strongly influenced by the turbidity of the water. If the turbidity is higher then the incoming sunlight will be lower and result in a low level of brightness. The brightness of a water indicates the extent to which sunlight penetrates the water layer and can be used for photosynthesis [17].

Table 4. Chemical parameter data in the Way Kalam Waterfall stream

\begin{tabular}{|c|c|c|c|c|c|}
\hline \multirow{2}{*}{ No } & \multirow{2}{*}{ Parameter } & \multicolumn{3}{|c|}{ Station } & \multirow{2}{*}{ Quality Standards } \\
\hline & & $\mathrm{I}$ & II & III & \\
\hline 1 & $\mathrm{pH}$ & 7.8 & 7.7 & 7.6 & $6-9$ \\
\hline 2 & DO & $4.8 \mathrm{mg} / \mathrm{l}$ & $4.6 \mathrm{mg} / \mathrm{l}$ & $4.7 \mathrm{mg} / \mathrm{l}$ & $4 \mathrm{mg} / \mathrm{l}-6 \mathrm{mg} / \mathrm{l}$ \\
\hline 3 & COD & $71.13 \mathrm{mg} / \mathrm{l}$ & $64.7 \mathrm{mg} / \mathrm{l}$ & $72.8 \mathrm{mg} / \mathrm{l}$ & $100 \mathrm{mg} / \mathrm{l}$ \\
\hline 4 & BOD & $22 \mathrm{mg} / \mathrm{l}$ & $12 \mathrm{mg} / \mathrm{l}$ & $18 \mathrm{mg} / \mathrm{l}$ & $30 \mathrm{mg} / \mathrm{l}$ \\
\hline
\end{tabular}

The appropriate $\mathrm{pH}$ value for the aquatic environment ranges from 6-9 as stated in the Government Regulation of the Republic of Indonesia (PP no. 82 of 2001) concerning Water Quality Management and Water Pollution Control. Based on the $\mathrm{pH}$ measurement data at the three stations, the difference is not too far, the highest $\mathrm{pH}$ value is at station I with a value of 7.8 and the lowest $\mathrm{pH}$ value is at station III with a value of 7.6. The measurement results are included in the appropriate range of water quality standards.
As described in the results of research in the journal "Marine and Aquatic Science" which says that for aquatic biota the $\mathrm{pH}$ value is not less than 5 and not more than 9 , the $\mathrm{pH}$ value range is very favorable for the life of aquatic biota where the results of this study obtained a $\mathrm{pH}$ range on all stations between 7,6 until 7.8 which means the waters are still classified as good for the metabolism of aquatic biota [14].

The measurement data for DO or dissolved oxygen ranged from $4.6 \mathrm{mg} / \mathrm{l}-4.8 \mathrm{mg} / \mathrm{l}$ with the highest DO value being at station I and the 
lowest value being at station II. The measurement value is still within the range of the appropriate quality standard values, so it can be said that the waters of the Way Kalam Waterfall are still relatively good. The DO measurement results in this observation are in accordance with what is described in the alkimiya journal regarding "Determination of River Pollution Levels Based on the Composition of Macrozoobenthos as Bioindicators" that the high DO is influenced by water temperature, temperature greatly affects the solubility of oxygen in a waters. If the temperature rises, the oxygen content in the water will decrease, not only the temperature of the sediment type also affects the high DO. In the results of the study it was found that at the third station the sediment was sandy which caused the oxygen content to be relatively high compared to areas that had mud sediments. If it is associated with the research conducted, all the observation stations have sediments in the form of gravel sand and rocks so that the value of dissolved oxygen obtained is also high [18].

The COD measurement results at the three stations ranged from $64.7 \mathrm{mg} / \mathrm{l}-72.8 \mathrm{mg} / \mathrm{l}$, where the highest COD value was at station III and the lowest COD value was at station II. COD measurement data obtained at the three stations looks rather high. However, this value is still included in the threshold criteria set by the Minister of Environment Regulation (No. 68/Menlhk/Setjen/Kum.1/8/2016) which is 100 $\mathrm{mg} / \mathrm{l}$. High levels of COD due to the lack of dissolved oxygen used by organisms to decompose pollutants that are difficult to degrade or difficult to decompose, COD levels that are not completely decomposed can result in accumulation and damage to aquatic ecosystems. In the Indopacific Aquatic Resources journal it is said that the research results in this journal are located at station 1 and station 3 , at station 2 the COD value decreased. The decrease in COD levels can occur because the organic levels that occur in these waters have decomposed, resulting in a decrease in COD levels at station 2 [19].

Based on the data from the measurement results of $B O D$ values at the three stations in a row starting from station I with the highest value of $22.0 \mathrm{mg} / \mathrm{l}$, station II with the lowest value of $12.0 \mathrm{mg} / \mathrm{l}$, and station III with a value of $18.0 \mathrm{mg} / \mathrm{l}$. However, the BOD values from the three stations are still below the appropriate water quality standard range according to the Minister of Environment Regulation (No. 68/Menlhk/Setjen/ Kum.1/8/2016) which is $30 \mathrm{mg} / \mathrm{l}$. BOD or Biochemical Oxygen Demand is the amount of oxygen needed by organisms in breaking down organic matter, decomposition of organic matter means that this organic material is used as food for organisms and the energy obtained comes from the oxidation process [17]. Similar to COD levels, BOD levels at station I were quite high and decreased BOD levels at station II. This is due to the large number of pollutants that enter the water so that it requires dissolved oxygen in large quantities. The entry of pollutants at station I is due to the activities of visitors who clean themselves using soap and shampoo which contain lots of chemicals and eventually settle to the bottom of the waters..

\section{CONCLUSION}

Based on research data analysis and discussion, it can be concluded that the diversity index values obtained at the three stations are station I $=1.124$, station II $=1.335$ and station $\mathrm{III}=1.205$, indicating that the diversity of macrozoobenthos found in the flow The Way Kalam Waterfall river is included in the moderate diversity category, and the quality of the waters in the Way Kalam Waterfall river flow which is seen based on biological parameters, physical parameters, and chemical parameters states that the waters are not polluted. 


\section{RECOMMENDATION}

Based on the research that has been done, there are several things that are suggested, namely the need to increase self-awareness for all of us about the surrounding environment, by preserving nature and not polluting the flow of the Way Kalam Waterfall. Periodic research is needed to monitor changes in physical and functional water conditions in the Way Kalam Waterfall river flow. The results of this study can be used as a learning resource and developed by educators on the subject of Biology Class $X$ Environmental Pollution Materials.

\section{REFERENCES}

[1] A. Soegianto, Ekologi Perairan Tawar,. Surabaya: Airlangga University Press, 2019.

[2] A. Nur Allifah, "Hubungan Kerapatan Lamun dengan Kepadatan Bivalvia di Pesisir Pantai Ori di Kecamatan Pulau Haruku," J. Biol. Sci. 2018, vol. 7, no. 1, pp. 81-96, 2018.

[3] J. Malam, Intisari Ilmu: Planet Bumi,. Jakarta: Erlangga, 2005.

[4] A. Kurniawan, Ekologi Sistem Akuatik: Fundamen dalam Pemanfaatan dan Pelestarian Lingkungan Perairan,. Malang: Universitas Brawijaya Press, 2018.

[5] H. Latuconsina, Ekologi Perairan Tropis: Prinsip Dasar Pengelolaan Sumber Daya Hayati Perairan,. Yogyakarta: UGM PRESS, 2019.

[6] Roziaty, Efri, Biologi Lingkungan,. Surakarta: Muhammadiyah University Press, 2017.

[7] Wahikun, Radioaktivitas pada Perairan Pesisir Cilacap,. Yogyakarta: Deepublish, 2016.

[8] et all Vinda Ester Pelealu, Grasideo, "KELIMPAHAN DAN KEANEKARAGAMAN MAKROZOOBENTOS DI SUNGAI AIR TERJUN TUNAN, TALAWAAN,
MINAHASA UTARA, SULAWESI UTARA," J. Ilm. Sains, 2018.

[9] et all Ridwan, Muhammad, "Struktur Komunitas Makrozoobentos di Empat Muara Sungai Cagar Alam Pulau Dua, Serang, Banten," Al-Kauniyah J. Biol., vol. 9, no. 1, pp. 57-65, 2016.

[10] M. Yusuf, Metode Penelitian Kuantitatif, Kualitatif \& Penelitian Gabungan,. Jakarta: Prenada Media, 2016.

[11] A. S. Leksono, Keanekaragaman Hayati,. Malang: Universitas Brawijaya Press, 2010.

[12] et all Estradivari, TERUMBU KARANG JAKARTA: Pengamatan Jangka Panjang Terumbu Karang Kepulauan Seribu (2003-2007),. Jakarta: Yayasan Terumbu Karang Indonesia, 2009.

[13] et all Fuad, M Arif Zainul, Metode Penelitian Kelautan dan Perikanan: Prinsip Dasar Penelitian, Pengambilan Sampel, Analisis, dan Interpretasi Data,. Malang: Universitas Brawijaya Press, 2019.

[14] M. Ulfa, G. S. H. Pande, and A. H. W. Sari, "Keterkaitan Komunitas Makrozoobentos dengan Kualitas Air dan Substrat di Ekosistem Mangrove Taman Hutan Raya Ngurah Rai Bali," Mar. Aquat. Sci., vol. 4, pp. 181-190, 2018.

[15] Y. Rosdatina, T. Apriadi, and W. R. Melani, "Makrozoobentos sebagai bioindikator kualitas perairan Pulau Penyengat, Kepulauan Riau," J. Pengelolaan Lingkung. Berkelanjutan (Journal Environ. Sustain. Manag., vol. 3, no. 2, pp. 309-317, 2019, doi: 10.36813/jplb.3.2.309-317.

[16] S. P. Oktovianus Leatemia, E. Manangkalangi, P. Theresia Lefaan, $\mathrm{H}$. F. Zakeus Peday, and L. Sembel, "Benthos Macroinvertebrates as Bioindicator of Water Quality in Nimbai Stream at Manokwari, West Papua," J. Ilmu Pertan. Indones., vol. 22, no. 1, pp. 25-33, 2017, doi: 10.18343/jipi.22.1.25. 
[17] R. S. Hasibuan, "Kajian Kualitas Air Sungai Ciliwung," J. Nusa Sylva, vol. 17, no. 2, pp. 91-100, 2017.

[18] R. I. N. A. B. U. D. I. S. Atriarti, S. U. C. I. W. U. P. Awhestari, M. Erliyana, and D. A. N. N. U. W. Idianti, "Komposisi Makrobentos Sebagai Bioindikator," vol. 5, no. 2, pp. 57-61, 2019.

[19] P. Herawati, T. A. Barus, and $H$. Wahyuningsih, "Keanekaragaman Makrozoobentos Dan Hubungannya Dengan Penutupan Padang Lamun (Seagrass) Di Perairan Mandailing Natal Sumatera Utara," J. Biosains, vol. 3, no. 2, p. 66, 2017, doi: 10.24114/jbio.v3i2.7434. 